\title{
The Franchise Squabbles between the Government and Media: Its Financial Consequences towards the Stakeholders
}

\author{
Hilario V. Manongtong \\ larry_vm@yahoo.com.ph \\ Institute of Graduate Studies \\ San Sebastian College Recolletos Manila, Philippines
}

\begin{abstract}
The franchise squabbles between the government and media broadcasting networks pose a severe problem to the access of news and information to the people, which is critical in functioning society and carries grave financial consequences to the Network's stakeholders. Such was the case of XYZ Network after it failed in its bid to get a new government franchise to continue its free-to-air television and radio broadcasts in country $\mathrm{X}$ airwaves. The legislature did not renew the XYZ Network's franchise after finding some violations in the franchise provisions. The observers perceived the apparent displeasure of the country's head of state purportedly due to the Network's biased reporting and unlawful practices as a factor also in its nonrenewal.

The stakeholders are the ones who are the underdogs in this squabble, financially. Before its shutdown, XYZ Broadcasting Company is the leading company with billions of assets. It has thousands of employees and several partners in the industry. It is also a key driver in the advertising industry due to its wide range of audiences. On the other hand, the government collects a vast amount of taxes, essential in national development.

Considering the far-reaching impact of the franchise non-renewal of XYZ Network in providing access to news and information to the public, the financial gains to the shareholders, and contributions to the economy, the government must have taken a conservative stance in its verdict on its renewal. The government may have explored all possibilities of extracting accountability from the company without necessarily shutting down its broadcast permit.
\end{abstract}

Keywords: Franchise squabble; Franchise non-renewal; Network shutdown; Financial consequences 


\section{Introduction}

A media company needs authorization from the government before it can engage in broadcasting. To be able to use the airwaves, a franchise is awarded to the company by the state. The exercise of this temporary privilege by the franchisee comes with some form of public service.

Television and radio broadcasting are among the primary sources used by people for news, public service, entertainment, and other data. The government should recognize one of the media's crucial functions, disseminating the information towards the public's interest. Broadcasting companies should be allowed to utilize the free airwaves through franchise grants for commercial broadcasting. In return, these companies are obliged to provide adequate public service to enable the government to reach the population regarding critical issues, promote balanced and sound programming, and pay taxes from all income derived from operations.

These broadcasting networks play a huge role in contributing to the economy. The potential of advertising in broadcasting and entertainment programs allows media organizations to generate enormous revenues resulting in high tax collections for the government. Media companies are also among the top employers due to their complex and labor-intensive operations. These make the media entities even more vital in news and public affairs and their country's economic growth.

These businesses produce various entertainment programs shown on free-to-air television. Aside from television, they would also offer radio broadcasting. These companies should have strong stations located in major cities in their country.

The company XYZ has subsidiaries and associates engaged in different businesses like video and audio recording and distribution, film distribution, movie production, cable distribution, telecommunications, and merchandising. Its television outfit has cable channels, which air its entertainment and news programs. Infrastructure-wise, the company has state-of-the-art technologies that allow it to reach even far-flung areas. It also has an estimate of several thousands of employees. XYZ Network is the biggest in terms of total assets and gross revenues while its closest rival has less than $50 \%$ as compared with it.

XYZ Network is in the best position in the industry and maintains a very positive business outlook but the revocation of its broadcast franchise by the government jeopardized it.

\section{Statement of the Problem}

With the franchise non-renewal, XYZ Network ceased its free-to-air broadcast operations. Some of its subsidiaries closed, while others voluntarily terminated due to non-viability. The Network retrenched numerous employees in the aftermath of the closures. The timing of the shutdown during the COVID-19 
pandemic made the situation even worse. As many businesses closed, the employees and talents who separated from the company were in a quandary.

As an immediate repercussion of the shutdown, the company registered a significant decrease in revenues, mostly from advertisements. The value of the firm's stocks dived down as an instant market reaction. Also affected by the closure are the suppliers of products and services directly or indirectly doing business with the Network. Another negative impact is the amount of tax due to the government expected to be lost.

The absence of free-market competition due to the XYZ's Network continued shutdown of its freeto-air broadcast is also a problem. $\mathrm{XYZ}$ and its close competitor account for more than half of viewership. XYZ's closure led to a certain level of monopoly in favor of its rival Network, resulting in a disadvantageous situation for the businesses that were highly dependent on television and radio for advertising exposure. In Economics, inelastic goods or goods that do not have comparable substitutes are ruled strictly by the law of supply and demand. This principle holds that low supply and high demand lead to higher prices. The shutdown of the XYZ network that delivers broadcast, a "perishable product" may lead to higher advertising costs for these companies.

The non-renewal of XYZ's free-broadcast license has damaging effects in the billion-dollar advertising industry. Many big businesses consider traditional advertisements through broadcast media as a critical component of their promotional mix. Many advertising agencies had laid off several of their employees with the cessation and experienced a decline in revenues.

The avid supporters and consumers of the Network who are adamant to shift to other media companies would have to deal with higher costs of availing cable services or using the digital platform. According to the studies, in country $\mathrm{X}$, television audiences consistently demonstrate a high level of loyalty to their Network of choice. This response from customers reveals what is called "attitudinal loyalty." Strong attitudinal loyalty makes customers more resistant to attempts by other marketers to steal them away (Gundlach et al., 1995) and more resistant to counter persuasion and search for alternatives (Dick and Basu, 1994).

The shutdown of the Network may have a detrimental outcome also to the creditors. XYZ company was able to invest in technology and infrastructure through billions of debts and bank loans. While its present financials show its capacity to pay its debts, its broadcasting activities' shutdown may reverse it in the long run. 
Another likely consequence is on the investor's confidence. The government shutting down a media outfit as big as XYZ Network, even considered one of the industry pioneers, negatively affects the investor's confidence in business security in country $\mathrm{X}$.

Finally, the most affected sector in this row is the viewing public or consumers. The lack of players in the industry creates a vacuum. It deprives the consumers of the choices for quality programs and access to reliable information at a low cost that arises from the competition among media organizations. In economic parlance, the competition promotes efficiency.

\section{Cause of the Problem}

The allegations which hound the Network during the legislative deliberations of its franchise renewal included the following contentious issues:

Question in ownership

The owner of XYZ Network had problems in terms of citizenship status. The statutes require the franchisee to be companies wholly owned by its citizens. The owner's situation made his allegiance to the country implausible.

\section{Unlawful labor practices}

The not-so exemplary labor practices included labor law violations and the Network's failure to regularize many of its employees. XYZ Network utilized what they call a "project-based" work arrangement for its employees since there were no existing anti-contractualization laws in this country. Aside from this, these are "projects" since shows were seasonal, which rendered the works temporary.

\section{Biased reporting and political meddling}

The proponents of the franchise non-renewal believed that the company exhibited bias in reporting against the government, and some of its actions bordered on political interference. For instance, in the headlines for a specific country on the alleged illegal drugs, XYZ Network only focused on minimal data that only featured the story's negative side. Unlike the other Network, which stated all the story's empirical facts, the viewers are fully aware. The head of state had been vocal of the disapproval of the franchise renewal on account of these grounds. 
Non-payment of correct taxes

While not illegal, the dissenters of the franchise grant opined that the Network's tax avoidance is prejudicial to the government in light of the lost revenues to serve the people's basic needs. Tax avoidance denotes the use of legal methods to reduce taxes owed by businesses to the government.

Due to these reasons, XYZ Network could not renew its franchise for free radio and television broadcasting. The company had debunked the accusations hurled against it and maintained its faithful compliance to the law. Many economic observers shared that the government should give the Network more latitude, considering that the government's regulatory bodies had not expressed categorical statements that the company committed grave offenses to warrant its broadcast franchise's junking.

\section{Courses of Action}

The XYZ network should honestly and objectively evaluate its operations and performance vis-a-vis its franchise mandate compliance. It must adequately address the issues thrown at it and take corrective measures. It must continue to improve its services, mindful of its responsibility to the government and stakeholders as a broadcast institution. In so doing, the Network positions itself better to appeal for a franchise in the future.

To be afloat sans broadcast franchise, the company should consider entering a business partnership with other media entities in the regions where it can air its programs. It has to keep creating excellent products and media content to stay relevant and competitive.

The company has to consider shifting to or increasing its penetration in digital platforms. The recent years have seen growing interactions in the digital space. Digital platforms are online businesses that facilitate interactions between at least two groups. Examples of these are the social networking platform (Facebook), the professional networking platform (LinkedIn), the micro-blogging platform (Twitter), and YouTube. These are powerful platforms to televise public affairs and entertainment programs and generate revenues from online advertisements and the sale of online content.

Lastly, XYZ Network has to re-launch its franchise renewal application at an opportune time. While there is a presumption of regularity in the government's action, one cannot discount the franchise renewal's political aspect since the one who makes the decision is the lawmakers who have different political leanings and considerations. The Network must take its chance in a different political environment. 


\section{Conclusion}

The franchise squabble between the government and media is disadvantageous to all its stakeholders. The franchise non-renewal of a television network like XYZ has considerable adverse financial consequences to its stakeholders, including employees and talents, the advertisers, suppliers and creditors, the government, the economy in general, and many others. For this reason, it is a sensible decision, and in the interest of the viewing public and all its stakeholders, to grant a broadcast franchise to XYZ Network. Without the necessity of denying a franchise, the company may be held accountable for the alleged violations by imposing stringent penalties if warranted.

The government and the Network must work together, without encroaching on each other's independence, but only having in mind the people's best interest, which is the fundamental objective of broadcasting.

Faced with its broadcast franchise revival uncertainty, XYZ Network must continue its business, especially in creating competitive programs and distribute them through a business partnership with other media entities and digital platforms.

\section{Recommendation}

Considering the critical role of broadcasting in disseminating public information, delivery of public service, and the economy in general, the government should reconsider its decision and grant XYZ Network the broadcast franchise. The government should also revisit its franchise regulations to ensure that the regulatory bodies have enough supervision and punitive powers to immediately correct the franchise holders' violations without waiting for franchise renewal to address them. On the other hand, the franchisee must faithfully comply with its duties and obligations to the state and its stakeholders, recognizant that a franchise is a matter of privilege bestowed by the state.

\section{References}

Ball, D., Coelho, P., Machas, A. (2004). The role of communication and trust in explaining customer loyalty: an extension to the ECSI model. European Journal in Marketing. DOI:10.1108/03090560410548979

Bates, B.J. (1985). Economic theory and broadcasting. Retrieved from https://files.eric.ed.gov/fulltext/ED258216.pdf?fbclid=IwAR2uXRN7TBQepmuqinD55sLRdRY6tay wD8_84Hd0HzcF6gAWJSKYfd6zCt4 
Becker, L.B. Hollifield C.A., Vlad, T., (2006). The effects of political, economic, and organizational factors on the performance of broadcast media in developing countries. Retrieved from https://grady.uga.edu/coxcenter/Activities/Act_2005_to_2006/Materials0506/Egypt/IAMCR2006_Pol_Com_Final_version_v2.pdf?fbclid=IwAR3AE49g7BIlV22YrHtaB4xC HTZIyRXu-dhddEOB_p-T9cYo7KGGenj1FPQ

Doberger, S. and Middleton, J. (March 2005) Franchising in Practice: The Case of Independent Television in the UK, Fiscal Studies 6(1) 17-33 DOI: 10.1111/j.1475-5890.1985.tb00397.x

Eltzroth, C. (2006). Broadcasting in developing countries: elements of a conceptual Framework for reform. Retrieved from https://dl.acm.org/doi/10.1162/itid.2006.3.1.19?fbclid=IwAR1oPToEd8Nd_yIOGVSE7X9BaoLFHok4-JUHEizG6JmXdg6afQrbuloQLk

Introduction to Media Economics. Retrieved from https:/www.sagepub.com/sites/default/files/upmbinaries/9436_010539Intro.pdf?fbclid=IwAR2sBuEXUso etA8snUzupXJdZc554KA7bbWzGgXQnZS8ugnUE16KH7ys_o

ITIF Technology Explainer: What Are Digital Platforms? (2018). Retrieved from: https://www.bmc.com/blogs/digital-platforms/

Loggie, N. (2020). Why advertising is essential to any kind of business.

Retrieved from https://www.adlibweb.com/why-advertising-is-essential-to-any-kind-ofbusiness/?fbclid=IwAR3Pw_mYkzuXfa2tu7zkPQBm2hR3L1Hh1MV_Fib2b1mmEhpYvU0ZyUie20

Media Development Investment Fund. (2019). Media development's role in social, economic, and political progress. Retrieved from https://www.mdif.org/wpcontent/uploads/2019/07/Media-Developments-Role-in-Social-Economic-and-Political-ProgressLiterature Review.pdf?fbclid=IwAR1WoXH6HyBIxjEV3uyUos7zWNHxM2wF2SRKeTAGWOBWu_GimB1 B6M8aV3M

Robles, C. Philippine laws, statutes \& codes. Retrieved from https://www.chanrobles.com/republicacts/republicactno7966.html?fbclid=IwAR2uFIGOWljI0oSXX x2DAHG5waViUFNNh12bP8sM969xcaaZq1mzG3CA1No\#.X_W1utgzbIV

Watts, S. (2020). Digital platforms: a brief introduction. Retrieved from https://www.bmc.com/blogs/digitalplatforms/?fbclid=IwAR2e5omNjkHsP3NV9Lr2oD3ChI3Bx8IeIhrNDUN9vz4ZDF4zQ_nbCucnseY 
Withers, G. (2002). Economics and regulation of broadcasting. Retrieved from https://openresearchrepository.anu.edu.au/bitstream/1885/41411/3/No93Withers.pdf?fbclid=IwAR2q XCj9VN6X1RG02nIP7sGl4nglq-xq-d1gQofom-EDJWgnBxCgsVXELvQ 